\title{
Podobe modernosti v prvencu Janka Silana $\check{C} u k i^{1}$
}

\author{
Edita Príhodová \\ Katolícka univerzita v Ružomberku, Hrabovská cesta 1, \\ SK-03401Ružomberok, prihodova@ff.ku.sk
}

\begin{abstract}
V zgodovini slovaške književnosti je Janko Silan zapisan kot najpomembnejši pesnik slovaške katoliške moderne in duhovni pesnik par excellence. Članek se osredotoča na interpretacijo njegove debitantske zbirke $\breve{C} u k i$ (Kuvici). Analiza figurativnosti in stilizacije lirskega subjekta odkriva inspiracijo s slovaškim, češkim in francoskim modernizmem. Ob tem je v okviru simbolistične poetike uporabil tudi folklorne teme. Poetiko Silanove debitantske zbirke bi lahko označili kot simbolistični, včasih celo dekadentni modernizem.

In the history of Slovak literature, Janko Silan is a well-known poet of Slovak Catholic modernism and spiritual poetry. This article outlines an interpretation of his debut collection, Kuvici. Silan's use of figurative language and the stylizations of his lyric subject reveal that he was inspired by the poetics of Slovak, Czech, and French modernism. We can categorize his style as a symbolic, sometimes decadent, modernism. Silan used motifs from folklore. He created an unique original poetic world in the centre of which is depicted the problematic nature of human life.
\end{abstract}

Ključne besede: slovaška književnost, katoliški modernizem, Janko Silan, simbolika, duhovna poezija

Key words: Slovak literature, Catholic modernism, Janko Silan, Symbolism, Spiritual poetry

\section{Uvod}

V zgodovini slovaške književnosti je Janko Silan zapisan kot najpomembnejši slovaški spiritualni lirik 20. stoletja (Zambor 1998: 40). Hkrati se polarizira

\footnotetext{
${ }^{1}$ Članek je del izvedbe projekta VEGA 1/0600/10 Slovaška katoliška moderna v evropskem kontekstu.
} 
razlika med Jankom Silanom kot pesnikom, čigar poezija izhaja iz notranje izkušnje (Hamada 1994: 163), ter med drugimi pesniki slovaške katoliške moderne, predvsem Pavlom Gašparovičem Hlbino in Rudolfom Dilongom, ki sta se v svoji poeziji približala senzualizmu in estetizmu (Hamada 1994: 143).

Osnovni cilj članka je predstaviti pesnika slovaške katoliške moderne Janka Silana na podlagi interpretacije njegove zbirke $\check{C} u k i$ (Kuvici). Pri interpretaciji se bom osredotočila na kategoriji senzualnosti in modernosti, ki ju bom identificirala s pomočjo izraznih in semantičnih oblik figurativnosti in stilizacij lirskega subjekta. Prvenec $\check{C} u k i$ je za bralca in za interpretacijo privlačna, ker priča o malo znani, temni strani Janka Silana. V primerjavi z duhovno poezijo zbirka Čuki Janka Silana predstavlja pesnika osebne, modernistično obarvane poezije. Literarna zgodovina je sicer mnogokrat našla povezavo Čukov s slovaško in tujo modernistično književnostjo, a do sedaj ta povezava ni bila potrjena $\mathrm{z}$ interpretacijo. Iskanje izvora metaforike in izrazov moderne $\mathrm{v}$ prvencu Janka Silana je zato odprto in za interpretacijo provokativno vprašanje.

Izhodišče sta pojma umetniške in literarne moderne, ki se je časovno pojavila na prelomu 19. in 20. stoletja; poetološko je bila navdih v času prve polovice 20. stoletja. Umetniška moderna je bila odraz filozofije življenja, filozofije iracionalizma in intuitivizma, nasproti racionalizmu in sistematični filozofiji sploh (na Slovaškem je literarna zgodovina opazila predvsem navdihe Arthura Schopenhauera, Friedricha Nietzscheho in Henria Bergsona). Za moderno je bila značilna želja po zapolnitvi sedanjosti s svojo estetsko sliko in slikanjem sveta, razpad celotne podobe človeka in hkrati kruto, čeprav včasih odvečno, prizadevanje za to celoto. Umetnost moderne s svojo visoko cenitvijo originalnosti problematizira tradicijo, toda posamezni avtorji tradicijo sprejemajo različno (Cvrkal 1995: 3-5). Pojem modernosti pa razumem tudi kot estetsko kategorijo, v katero uvrščam tiste načine umetniškega ustvarjanja, ki se z moderno izrazito ujemajo, čeprav bi lahko obstajale tudi v drugih obdobjih: $\mathrm{v}$ zgodnejših, npr. v romantiki, in tudi pozneje, v sodobni književnosti, inspirirani z moderno (Nünning 2006: 522). Povezava poetike Čuki bo v tem smislu izraz moderne, ne moderne same, ker je slovaška književnost $v 30$. letih 20 . stoletja že zaznala razvojni impulz avantgarde, predvsem poetizma in nadrealizma.

\section{Slepi trubadur Janko Silan}

Pesnik in duhovnik Ján Ďurka z umetniškim imenom Janko Silan (1914-1984) je svoje pesmi začel objavljati v 30. letih 20. stoletja v relativno širokem spektru slovaških verskih in literarnih revij. Leta 1936 je s pomočjo češke štipendije Knjižnice sklada Juliusa Zeyerja pri Češki akademiji znanosti in umetnosti v Pragi izdal svojo prvo zbirko $\breve{C} u k i$. To je bil začetek osebnih in literarnih stikov Janka Silana s češkimi književniki (J. Demlom, J. Zahradníčkom, J. Čepom, M. Trávníčkom in drugimi).

Po vstopu v semenišče je Janko Silan izdal pesniško zbirko Lestev v nebesa (Rebrík do neba, 1939), v kateri se je za vedno obrnil k spiritualni tematiki. 
V okolju semenišča v Spišski Kapituli je nastala tudi zbirka Slavimo to skupaj (Slávme to spoločne, 1941), za katero je bila navdih smrt pesnikove matere. S pesniškim ustvarjanjem Silan ni prenehal delovati niti kot duhovnik. Kot kaplan v tatrskih vasicah Javorina, Ždiar in Liptovský Hrádok je izdal pesniške zbirke, ki veljajo za vrhunske primere spiritualne lirike v slovaški književnosti. Gre za zbirke Dokler ne bomo doma (Kým nebudeme doma, 1943), Pesmi iz Javorine (Piesne z Javoriny, 1943) in Pesmi iz Ždiara (Piesne zo Ždiaru, 1947). V tem obdobju se je Janko Silan ob izvirnem pisanju posvečal tudi prevajanju iz nemščine (R. M. Rilke) in latinščine (verske himne). Leta 1948 mu je še uspelo izdati zbirko Uboga duša na zemlji (Úbohá duša na zemi). Takoj zatem je nova totalitarna politična oblast ukinila založbo in revijo Verbum, katerih soustanovitelj je bil Janko Silan, in mu preprečila pisati ter udeleževati se literarnega življenja. Od leta 1949 je Silan kot katoliški duhovnik živel v ozadju in v zelo revnih razmerah pod Tatrami v vasi Važec.

Politična in kulturna liberalizacija družbe v 60. letih je tudi Silanu za kratek čas odprla možnosti za objavljanje. V drugi polovici 60. let so izšli izbor njegovih del Sam z vami (Sám s vami), bibliofilski Triptih 1-4 (Triptych 1-4) in pesniška zbirka Obsijanje (Oslnenie). Za tisk je imel pripravljena tudi druga besedila, a je politična oblast v obdobju normalizacije njihovo objavo preprečila. J. Silan je kot pesnik ponovno neprostovoljno umolknil vse do svoje smrti leta 1984. A že leta 1990 je izšla zbirka Pesmi iz Važca (Piesne z Važca), ki obsega njegovo poezijo med letoma 1950 in 1980. Leta 1991 je izšel njegov edini, več desetletij pisani roman Hiša zapuščenosti (Dom opustenosti), v katerem na sugestiven način predstavlja človeško, sanjsko in duhovno izkušnjo, zabeleženo v dnevniku glavnega junaka, mrtvega duhovnika. Med letoma 1995 in 1998 je založba Lúč izdala Silanova Zbrana dela v osmih knjigah in tako bralcem omogočila dostop do njegovega literanega ustvarjanja. Od 90. let se je Silanovemu ustvarjalnemu delu znanstveno in uredniško posvečalo več slovaških literarnih znanstvenikov, ki Silana štejejo za značilnega pesnika slovaške katoliške moderne. Iz navedenih dejstev izhaja, da literarno delo Janka Silana predstavlja vrednote, ki tudi po več desetletjih pritegnejo pozornost.

\section{Vtis, podoba, človek v zbirki Čuki}

Oblike in pomenske premike med stilizacijami lirskega subjekta lahko podrobneje spremljamo na podlagi kompozicije zbirke. Pesnik je namreč v prvencu (kot tudi v kasnejših zbirkah) pesmi uvrščal v posamezne dele zbirke, pri čemer ga je vodilo načelo funkcionalnosti. Posamezne pesmi je na podlagi skupnih semantičnih in izraznih elementov združeval v večje kompozicijske celote, kar pri branju in interpretaciji razvija proces identifikacije, diferenciacije in sintetizacije pomenov. Hkrati je treba poudariti, da vključevanje pesmi v večje kompozicijske celote ni mehanično in med posameznimi deli ne ustvarja definitivnih meja. Nasprotno, skupni poetološki elementi konotirajo semantične pomene na kompozicijski ravni, višji od pesmi. Namige in preseganje meja 
pesnik izrablja hkrati s semantičnim in kompozicijskim razmejevanjem. Interpretacija, ki metodološko izhaja iz členitve zbirke na kompozicijske celote, omogoča razkrivanje več polifonskih slojev figurativnosti in modernosti, ki se pred bralcem postopoma razkrivajo $\mathrm{v}$ zbirki kot celoti.

Prvi del zbirke ima naslov Zoborske poti (Zoborské cesty). Zobor je namreč kot geografski prostor na srednjem Slovaškem (hrib pri mestu Nitra) povezan $\mathrm{s}$ pesnikovim otroštvom in mladostjo. Nasprotje natančno lokaliziranih prostorov so simbolistični prostori, npr. pristava, dolinica - obe izražata semantiko, povezano s smrtjo (podzemlje, pokopališče). S smrtjo je povezan motiv bolečih oči kot vzrok osebne bolečine lirskega jaza. Lirski subjekt, ki je individualiziran kot tisti s krvavimi očmi (Metamorfoza/Metamorfóza), preživlja boleče videnje kot umiranje v lepoti in za lepoto: »A potom nedbám, nech už vykrváca / zrenica oka v kráse labutej« (Brez odgovora/Bez odpovedi). Pesnik oči povezuje s krvjo kot životvorno substanco, kar zveni izrazito ekspresivno. Poleg neposrednega motiva oči pesnik uporablja tudi motiv solz, ki priča o možnosti za neverbalno izražanje čustev. Vizualna podoba posreduje tudi sprostitev napetosti, a ne gre za čutni dražljaj, ampak za sanje ali privid, torej za vizualizacije, povezane s podzavestjo, ki jih je odkrila moderna poezija.

Tavanje lirskega subjekta po ovinkastih zoborskih poteh z enim samim ciljem - smrtjo je povezano z napornim vzponom, s hojo navkreber. Zgovorna je končna rima navzgor - Zobor (Zobor), ki jo lahko imano za vertikalno metaforo. Zobor ni le fizičen, ampak tudi metafizičen prostor. Premik semantike Zoborskih poti je povezan z drugimi čisto metafizičnimi prostori (nebesa), ki jih lirski subjekt išče in se jim približuje. »Tak blizko nám je obloha, / ach božský oltár veleby, / len jedna noha, polnoha / - a už sme, už sme na nebi.« (Zobor). Metafizičen oziroma natančneje eshatološki pomen je povezan z motivom mrtve in svete matere. Eshatološki pomeni v delu Zoborske poti za lirski subjekt predstavljajo sproščujoči moment, ker v prividih mrtve matere lirski subjekt najde tolažbo, vendar gre za subjektivno verovanje, za katero je značilna predvsem vera v posmrtno življenje in je osredotočeno na estetizirano ter sakralizirano podobo matere. V kombinaciji s stilizacijami lirskega subjekta kot potepuha in izobčenca, obsojenega na brezciljnost in smrt, zveni semantika eshatoloških motivov iz prvega dela zbirke bolj modernistično kot spiritualno.

Posebnost drugega dela zbirke $\mathrm{v}$ primerjavi z ostalimi kompozicijskimi celotami je, da ima enak naslov kot naslov zbirke - Čuki. Kot nočni ptiči, ki se oglašajo s predirljivim zvokom in ki letajo proti svetlobi (kjer se zbira nočni mrčes), so čuki v folklorni tradiciji postali sli smrti. Simbol čukov izmed vseh podob in simbolov, uporabljenih v zbirki, senzualno najizraziteje izraža fatalistično usojenost smrti. Konkretno v pesmi Čuki pesnik v pretirani meri apelira na čute, $\mathrm{s}$ čimer želi pozornost bralca usmeriti na prisotnost predsmrtnih in smrtnih znamenj: »Okná sú pozastreté fialovou záclonou, / v svietniku čiernom plače bledá svieca, / zúfalé melódie pod vyschnutou jabloňou / nesú sa nocou a o čomsi strašnom svedčia.« Izrazita vizualizacija pogrebnih rekvizitov je povezana s slušnim in čustvenim izražanjem antropomorfiziranih pojavov (sveča joče, melodija je obupana). Poleg čutne metaforike pesnik izrablja tudi 
slutnjo, intuicijo bralca (zadnji, četrti verz odlomka) in ker gre za kulturno določene simbole (vijoličasta barva, posušena jablana), tudi njegov kulturni spomin. Naslednja kitica razvija motiv čukov in ga postavlja v odnos z neimenovanim človekom, ki ga opredeljuje želja po smrti: »Kuvici-spevci večerných a nočných serenád / vábivo vábia do noci. A na okná / sadajúc vyčkávajú toho, čo chce umierat', / a nechcú preč, hoc zaháňa ich rúčka belostná.« Obupana melodija iz prve kitice je hkrati serenada, nočna ljubezenska pesem, s katero čuki pri človeku vzbujajo hrepenenje in ga vabijo. Človek se obnaša paradoksno: vdaja se sugestiji čukovega glasu, hkrati pa čuke odganja in se smrti upira. Ta poteza, ki povzema ambivalentno obnašanje človeka do smrti, je tipična za celotno zbirko Čuki. Lirski subjekt se smrti vdaja kot nečemu omamnemu (napitek, zvok, lepota, ljubezen), usodno determiniranemu, a smrt dojema kot pogubo z občutkom žalosti in bolečine. V tretji kitici sledi podoba umiranja, srečanje življenja s smrtjo: „A vzdychy izbou rozosejú t’ažký tymian, / sviečka sa chveje, tuším hasne dusivo. A čiesi srdce roztvára si rany dokorán, / ked' na perne mrie smrtný najsmutnejši tón.« Pesnik tu niza tudi druge moreče in izrazito čutne izraze smrti, s katerimi aktivira voh in sluh. Med znamenji in dejstvi obstaja povezava: ugasnitev sveče in izzvenevanje glasu signalizirata smrt, ki jo zadnja kitica potrjuje: „Zazneje na skle okien smutné cirkumdederunt, / ked' poradia sa kňazi noci - kuvici;/ dunivým krokom l'udia máre zoberú / a nesú... A zvon zvoní v starej zvonici.« Zaključna kitica z uporabo slušnih vtisov vzbuja asociacijo na pogrebne obrede. Na semantično poudarjenem mestu na koncu verza pesnik z asonanco spaja besede kuvici-zvonici (čuki - zvonik) in serenád - umierat' (serenade - umirati), s čimer povezuje smrt z ljubeznijo, tartaros z erosom. Čuki se v metafori spiritualizirajo in dobijo status duhovnikov, s čimer se njihova vloga triadno zaključuje (tartaros - eros - sacros).

Simbol čukov in z njimi povezane semantične pomene, ki jih pesem $\breve{C} u k i$ zgoščeno izpoveduje, pesnik razvija v ostalih pesmih iz drugega dela zbirke. Silan poleg čukov uporablja tudi motiv lirskega jaza kot kukavičjega otroka (Fant/Chlapec). Semantične funkcije simbola čukov se torej dedno prenašajo tudi na človeka. Tanatološki motiv čukov Silan povezuje z motivi, ki izražajo smrt oči, npr. oči - slepi pavi, odrevenele oči, oči prizadetih po kapi (Poletni somrak/Letný súmrak). V paradigmo motivov smrti spadata tudi motiv neizpolnjene ljubezni do ženske in motiv ljubezni do mitoloških ženskih likov (rusalke, vile). Hrepenenje lirskega subjekta, da bi videl lepo žensko in potem oslepel, izkrvavel, umrl (Poletni somrak), je izraz modernega subjektivnega estetizma. Način sprostitve problemske napetosti iz prvega dela zbirke Zoborske poti (pogled v nebesa, sanje, privid matere) ni univerzalna rešitev. V drugem delu zbirke $\breve{C} u k i$ so se nebesa izgubila z obzorja, sanje pa so odpovedale kot simptomatična možnost za preseganje determiniranega sveta: »sny svoje biele rozbil chlapec čudný / o polámaný rám skiel svojich povestných « (Fant). V nasprotju $\mathrm{z}$ motivom matere iz prvega dela zbirke se tu - čeprav redkeje - pojavlja motiv očeta, od katerega lirski subjekt kot dediščino prejema eksistencialno usojenost smrti (Dediščina/Dedičstvo). Gre za mitološko in fatalistično rešitev: usodi ni mogoče pobegniti, mogoče jo je le spoznati, se ji podrediti, se z njo strinjati in 
jo izpolniti. A semantika pesmi kot celote in njihova poetika se oddaljuje od subtilno subjektivnega pesniškega simbolizma in se bliža dekadenci. Predvsem odnos lirskega subjekta do realnosti smrti kot nečesa, kar nanj deluje omamno privlačno, pojmujem kot mejo med subjektivno-simbolističnim in dekadentnim pristopom. Erotična in sakralna funkcija čukov je Silanov način erotizacije in sakralizacije smrti.

Tretja kompozicijska celota zbirke z naslovom Pod okni (Pod oknami) odkriva novo plast Silanove metaforike. Prostor Pod okni se ne nanaša več na čuke in smrt, ampak na lirski subjekt v novi, plahi ljubezenski stilizaciji. Pogost je motiv srca kot pesmi s pretežno erotično in subtilno osebno tenzijo (serenada, iskrena pesem), hkrati pa je poudarjena tudi njena dinamika (maestoso, andante, najtišja pesem). Iz istega semantičnega polja prihaja tudi motiv srca kot glasbila (srce - flavta, mandolina). Vsi ti sorodni motivi antropološki tenorski pomen izražajo z jezikom glasbe. Pesnik jih uporablja kot sinestezije, metaforične kratice, simbole in razširjene pesniške figure, ki jih na površini pesmi postopoma oblikuje.

Slušni motivi so semantično povezani z lirskim subjektom in z njegovim življenjskim občutjem. To se oddaljuje od žalosti in se čutno in čustveno odpira naravi, življenju, predvsem pa ljubezni do ženske. Uživanje življenja in senzualna odprtost ponovno širi obzorje lirskega subjekta vse do nebes, neba, raja. A gre za motiv erotične potešitve oziroma prostora, ki prikazuje želje lirskega jaza: »Budem t'a hojdat', ty si moja veleba, / spanilost' tvoja nech ma vedie do neba« (Strastna pesem/Pieseň vrúcna). Specifično je romantično poimenovanje privlačne ženske kot sestre (celo v poudarjeni obliki pomanjševalnice) in podobe erotizma, ki so zdravilne, pomirjajoče, uspavajoče, celo omiljene: »Načúvaj môjmu unylému mlčaniu / a srdce svoje, dušu, hlávku čačanú / pokojne zlož si do vankúšov mojich rúk, / sestrička moja sladká, l'aliový puk« (Strastna pesem). Erotizem in senzualizem vstopata v celotno tkivo sveta besedila. Nista le izraz izkušenosti lirskega subjekta, ampak tudi del figurativne ravni pesmi: »ratolest zvukov nových v srdci vykvitá; / tak dlho pri rieke som hladel na nebesá, / až bozkala ma hviezda slastou opitá ( (Iskrena pesem/Pieseň úprimná). A tretji del zbirke Pod okni je sestavljen tako, da se v zaključnih pesmih ponovno oglaša nemir čukov in modalnost žalosti, ki je ne more preprečiti niti erotična izkušnja (V oči/Do očí).

Četrti, zadnji del zbirke z naslovom Koraki slepcev (Kročaje slepcov) se navezuje na prejšnje dele. Napetost je tu v primerjavi z drugimi deli še bolj izrazita: razpad ljubezni in popolna odsotnost vida, ne le bolečina oči. Emocionalni register lirskega jaza tvorita žalost in predvsem razočaranje - uničenje sanj, privida, ljubezni. Človek lirski svet doživlja v čustvenih nasprotjih. Eksistencialno problematiko, ki je prikazana v senzualnih metaforah temè, mraza in trdote, pesnik sprošča $\mathrm{z}$ estetizacijo in poetizacijo resničnosti, ki je izražena s senzualnimi podobami beline, mehkobe in sublimirane kozmične erotičnosti.

Pesnik poudarja belo barvo sveta, ki je znak čutnega zaznavanja (zima, sneg), ki je povezano s tipalnim zaznavanjem mehkobe, ter panestetskega vtisa bele lepote. »Biele je všetko, všetko je dnes biele / sta mäkké husie perie... // a preto 
inej krásy - okrem bielej krásy - / na svete dneska niet « (Zimska pesem/Pieseň zimná). Kasneje je belina način idealizacije, estetizacije in simbolizacije preteklosti in sedanjosti lirskega subjekta in njegovega sveta. V obsežni demonstrativni pesmi Zimska pesem pesnik estetizirani in simbolizirani sintetični pojem vse postopoma zamenja za posamezne podrobnosti in sekvence: »Biele sú cesty, ktoré niekdy sivým prachom voňali.../ Biele sú výkriky a t’ažšie od olova ... « (Zimska pesem). Pesnik vizualno belo barvo s tipalnimi in slušnimi vtisi povezuje v sinestetične podobe in simbolizirano stvarnost monumentalizira (izrazito monumentalen je motiv petih krvavečih ran, ki se navezujejo na kristološki semantični kontekst). Za mnogimi podrobnostmi lahko odkrijemo več magnetnih polj, proti katerim se semantika »belih« podob zgošča: otroštvo lirskega subjekta, spomini na očeta, na mrtvo mater, misli o trpljenju in smrti. Konec pesmi, ki je sestavljen iz barvno kontrastnega motiva krvavih oči, ki so kot posušeno grozdje (»st’a usušené hrozná«), in iz besed o sestri, ki mi je oči prekrila z belo vato (»prikryla mi oči bielou vatou«), konkretizira izkustveni impulz za poetizacijo belega sveta. To ni le barva zime, snega, estetiziranih spominov in sublimiranih strahov, ampak tudi barva bolnišnice, v kateri je lirski jaz na operaciji oči. ${ }^{2} \mathrm{~V}$ njegovi zavesti se hkrati v lirskem toku podob in sinestezij medsebojno izmenjujejo spomini, sedanjost in strah pred smrtjo. Interpretacija, ki odkriva navdih pesmi, hkrati pojasnjuje pomenljivo množino v naslovu četrtega dela zbirke (Koraki slepcev) in množinsko - zborovsko obliko petja slepcev, ki se v drugih delih zbirke ni pojavila.

V zaključku četrtega dela se lirski subjekt kot slepec vrača in se spušča navzdol, v mesto, iz katerega je odšel (Nitra). S tem se pesnik navezuje na prvi del, v katerem je lirski subjekt s krvavimi očmi taval in se vzpenjal po zoborskih poteh. Kompozicija zbirke kot celote ima prosto epsko dikcijo, ki vzbuja občutek kroga in predstavo življenja kot blodenja v začaranem krogu. Podobno kot motivi gibanja, ki v kompoziciji zbirke tvorijo prosto epsko linijo, imajo tudi erotični motivi epsko in poetološko dinamiko v razponu erotično poželenje - decentni erotizem - erotična deziluzija - rast sublimiranega ete-

${ }^{2}$ Za sekundaren nebesedilni vir, ki potrjuje to interpretacijo, je lahko članek Jána Kováča Spominjam se pogovorov z Jankom Silanom (Spominam na rozhovory s Jankom Silanom), ki ga je napisal več desetletij pozneje (leta 1997) za uredništvo Lúč. Ján Kováč sprašuje o zbirki Čuki in parafrazira odgovor Janka Silana takole: »To je bila moja prva zbirka kot odmev na operacijo mojih oči, mojo bolečino, mojo nesrečo. Pri nas so ljudje govorili, da ko čuk, nočni ptič, skovika, to napoveduje nesrečo. A ker sem imel tudi jaz nesrečo z očmi, sem dal zbirki naslov Čuki« (Silan 1998: 46). Sam Silan v intervjuju z J. E. Borom leta 1994 osebni navdih za zbirko Čuki utemeljuje takole: »Čuki - to so moja študijska leta ... To so moji najbolj žalostni trenutki, ko so me izločili iz semenišča, ko sem se preživljal s prosjačenjem vseh vrst po ljudskih kuhinjah in vojaških kasarnah, z inštruiranjem in pesnikovanjem $v$ čeških časopisih. Treba je poudariti, da je pravzaprav skrivnost, kako sem doštudiral, ker mi oče zaradi lastne revščine ni mogel nikakor pomagati« (Silan 1998: 27). Čeprav med osebnimi razlogi Janka Silana za žalostni ton zbirke problema oči eksplicitno ni, ga je vseeno treba upoštevati kot razlog za izključitev iz semenišča. 
ričnega erotizma in koncentracija ženskih antropomorfnih likov. Pesnik tako zaključuje pesniško izpoved o izkušnjah lirskega subjekta kot potepuha, kukavičjega otroka in slepega trubadurja v zbirki $\check{C} u k i$.

\section{Oblike modernosti in navdihi zanjo v zbirki Čuki}

Pesniška besedila prvenca Janka Silana so prežeta z motivno subjektivnostjo in figurativno senzualnostjo. Najbolj stalno, v vseh kompozicijskih delih zbirke, se pojavlja vizualni motiv oči kot nosilec problemske napetosti. Vid je v zbirki Čuki najbolj metaforizirano, estetizirano in dramatizirano čutilo. Motiv krvavih oči in podoba lirskega jaza kot slepca sta tesno povezana z avtorskim kontekstom Janka Silana. Na splošno lahko o prvencu Janka Silana povzamemo, da je v njem v veliki meri uporabil motiv oči v paradigmi refleksivnega, problemskega modernistično-simbolističnega načina pisanja.

Silan svojo poezijo bogati tudi z drugimi čutnimi motivi - vohalnimi, tipalnimi in slušnimi. Pesniki moderne so glasbene motive pogosto uporabljali. To pomeni, da tudi tu lahko najdemo povezave med Silanovim prvencem in poetiko moderne. V slovaški poeziji so glasbeno metaforiko uporabljali Štefan Krčméry (Herbarij/Herbarium, 1929), Vladimír Roy (Pesmi/Básne, 1921), Ivan Krasko (Nox et solitudo, 1909) in drugi avtorji slovaške moderne. Hkrati več Silanovih zvočnih motivov zveni relativno eksotično ali vsaj tuje (serenada, arija, romanca, balalajka, mandolina, flavta - uporablja češko besedo flétna, op. prev.). Linija muzikalnih modernističnih motivov vodi od ustvarjalnosti avtorjev slovaške literarne moderne še dlje: do poezije čeških modernistov, predvsem Otokarja Březine, ki so jo slovaški avtorji katoliške moderne recipirali. ${ }^{3}$ Sled češkega vpliva niso le enaki poetični motivi (npr. motiv srca kot pesmi in flavte), ampak tudi enake leksikalne enote, ki so dokaz, da so bili modernistični poetični motivi v podzavesti bralcev povezani s češkim jezikom (besede flétna, pohádka, stesk, lkat', unylý, pocel, skráne).

Senzualni občutek je v poeziji Janka Silana pogosto pretvorjen v sinestetičen vtis. Sled navdiha v zgradbi sinestezije vodi do francoskega pesnika Charlesa Baudelaira ${ }^{4}$ in do njegovega koncepta povezanosti vonjev, barv in tonov (Baudelaire 1964: 22). V zgradbi sinestezije Janko Silan ne povezuje le čutnih vtisov med seboj, ampak tudi čute s čustveno ravnjo. Sinestezijo pesnik

\footnotetext{
${ }^{3}$ Iz članka Kaj govori Janko Silan o poeziji (Čo hovorí Janko Silan o poézii, 1948) izhaja, da je bilo Březinovo dojemanje literarnega ustvarjanja in naloge človeka/avtorja $\mathrm{v}$ književnosti za Silana navdih (Silan 1998: 114).

V zapuščini Pal’a Olive, Silanovega dobrega prijatelja in pesnika katoliške moderne, so lastnoročno prepisane Březinove pesmi (Gostíková: 2010). Slovenská národná knižnica, Martin, Archív literatúry a umenia, sign.: 210. Dostopno 14. 9. 2010 na: http://www.snk. sk/?xxviii.

${ }^{4}$ Njihovo pesniško delo so slovaški avtorji recipirali preko prevodov Vítězslava Nezvala (Pašteka 1998: 5-22).
} 
v zbirki Čuki produktivno uporablja pri razvijanju pesniških simbolov, ki na sinestetičen način izpovedujejo antropološke pomene, najpogosteje izkušnjo žalosti, razočaranja in smrti.

V skladu z življenjskim občutjem lirskega subjekta je tudi prostor, v katerem živi. Občutek tesnobe je povezan z ozkimi prostori (zadušljiva soba z zaprtimi okni v pesmi $\check{C} u k i)$, jama in kamnita hiša vzbujata občutek mraza (Baladna pesem/Pieseň baladická), nebo in nebesa se pojavljajo le v pesmih, kjer se problemska napetost lirskega subjekta sprošča s subjektivno samotranscendenco s pomočjo sanj ali prividov. Dežela duše dobiva splošne in tipične znake, ki jih je ustalila literarna moderna (megla, noč), a je hkrati povezana s specifičnim značajem »tega« Silanovega lirskega subjekta. V prvencu Janka Silana se pojavljajo konkretna srednjeslovaška mesta in njihova imena (Nitra, Zobor), toda gre za prostor, podvržen pesniški domišljiji: namigu, simbolizaciji, eksotizaciji. $Z$ estetizmom senzualistično razbremenjena stilizacija in občasno zračna kozmična motivika navdih povezujeta s poetizmom, konkretno v redakciji Rudolfa Dilonga (motiv fanta, sestre). A Janko Silan je eteričnost uporabil le za sprostitev napetosti (v korist lepote kot vrednote) in tudi v takih pesmih ni razpustil problemske napetosti $\mathrm{v}$ poetističnem dojemanju življenja kot igre ali sveta kot kabareta.

Pri motivu čukov in njihovih semantičnih pomenov lahko od daleč slišimo resonanco krokarjev A. E. Poeja, I. Kraska ali V. Roya. Sami čuki v pesniški moderni niso bili priljubljeni. S tem ko je Janko Silan izbral ta simbol, za katerega je navdih očitno našel $\mathrm{v}$ obeh virih $-\mathrm{v}$ folklori in literarni moderni - je njegovo konotativno moč še okrepil. Hkrati je s tem razširil repertoar modernističnih izraznih sredstev oz. odkril njihovo semantično analogijo z jezikom domače ljudske kulture. Na kompozicijski ravni zbirke $\breve{C} u k i$ je postopoma opazno naraščanje števila ljudskih motivov, ki jih pesnik aktualizira in modificira tako, da sicer kažejo na svoj prvotni folklorni kontekst, a hkrati tolmačijo subjektivistične pomene, ki so v skladu z avtorskim ciljem. Del te prvotno ljudske motivike je J. Silan izrabil tako, da je poleg ljudskega konteksta povezana tudi s slovaško romantično poezijo. Konkretno povezava motivov vode, ptičev, polomljenih kril in sanj, preobrazbe ter zaklinjanja spominja na poezijo Janka Krála (Zakleta devica v Váhu in čudni Janko/Zakliata panna vo Váhu a divný Janko, Povest/Povest'). Izrazito romantičen je tudi način spremembe ženske lirske junakinje v vilo, ki ga je uporabil Andrej Sládkovič v pesniškem delu Marína. Pozitivni odnos do obeh romantičnih avtorjev je Janko Silan ob več priložnostih pojasnil v svoji poeziji, pa tudi v pogovorih in člankih o svojem delu. ${ }^{5}$

Prvenec Janka Silana Čuki lirično izraža posebno avtorsko izkušnjo, kot je to razvidno iz izvora problemske situacije, v kateri se nahaja lirski subjekt (problem oči), pa tudi iz drugih elementov, npr. iz prostorske umestitve, iz

\footnotetext{
${ }^{5}$ Revija Slovenský rozhlas je leta 1948 objavila intervju z Jankom Silanom, kjer pravi: »Občudujem Sládkoviča in Janka Krála. V njih sta večen nasmeh ter solze naše dobre slovaške zemlje« (Silan 1998: 36).
} 
motiva mrtve matere in iz erotičnih motivov. Za motivom skupine trubadurjev, za katerega je značilen odklon od večinoma individualistično osredotočene problematike, lahko vidimo študente nitranske gimnazije, t. i. zoborske šturovce (med katere je Silan spadal), ki so hodili na sprehode na Zobor in tam recitirali pesmi.

\section{Zaključek}

Interpretacija debitantske zbirke Janka Silana $\check{C} u k i$ je odkrila težišče antropološke tematske linije pesniške izpovedi. Poleg stilizacij lirskega subjekta tudi semantična razporeditev figurativnosti potrjuje povezavo med antropološkim pomenom ter senzualnim, sinestetičnim in simboličnim izrazom. Avtoreferenčna izpoved lirskega jaza se giblje med tematskimi poli tartaros - eros - sacros. $\mathrm{V}$ skladu s tem so tudi tipi sproščanja problema in vzpostavitve miru v pesmi. Lirski subjekt doživlja subjektivno-versko, eshatološko sprostitev napetosti (videnje in spomini na mrtvo mater); mitološko-fatalistično olajšanje (v korist dekadentnega pozitivnega odnosa do smrti); estetično-erotično reševanje problema (želja videti lepoto in umreti) z modifikacijo erotizma (obravnavanje razpada erotičnih sanj $v$ ustvarjanju vesoljnih erotičnih podob in antropomorfiziranih ženskih bitij).

Na podlagi tega lahko pesniški slog Janka Silana tipološko označimo za subjektivno-simbolistični, občasno dekadentni modernizem. Janku Silanu je poetika simbolizma in modernizma ustrezala, ker je bila $\mathrm{v}$ skladu z njegovim avtorskim ciljem - problemsko upodobiti antropološke pomene. Ta odnos lahko ugotovimo kljub temu, da je začel Silan ustvarjati približno tri desetletja kasneje od avtorjev moderne. Čeprav ustvarjanje avtorjev slovaške literarne moderne ni bilo kvantitativno obsežno, so na kasnejšo slovaško poezijo ter na zgodnje ustvarjanje Silana delovali stimulativno. Iz registra modernističnih izraznih sredstev je Janko Silan izbiral sredstva, ki so ustrezala njegovemu lastnemu poetičnemu cilju (drugih pa ni uporabil, npr. blasfemičnega diabolizma dekadentov ali občutka krivde, značilnega za doživljanje lirskega subjekta $\mathrm{v}$ slovaški literarni moderni). V primeru vseh ugotovljenih usmeritev je Janko Silan ohranil kriterij funkcionalnosti in ustvarjalnosti. Funkcionalnost $\mathrm{v}$ smislu, da je izrazna sredstva izbiral tako, da so bila $\mathrm{v}$ skladu $\mathrm{z}$ njegovo lastno vsebino in temo. O ustvarjalnosti in izvirnosti govori dejstvo, da se v primeru vseh uporabljenih pesniških strategij kaže Silanov lastni način pesniškega izraza.

\section{LITERATURA}

Charles BAUDELAIRE, 1964: Květy zla. Praha: Mladá fronta.

Ján Elen BOR, 1944: Rozhovor s Jankom Silanom. Rozvoj 20/8, 189-191. 
Otokar BŘEZINA, 1984: Poezie přelomu století. Praha: Mladá fronta.

Ivan CVRKAL, 1995: Spektrum európskej moderny. Ur. Ivan Cvrkal. Bratislava: ÚSL SAV. 3-7.

Jana GOSTÍKOVÁ, 2010: Bibliografia J. Silana a P. Olivu. Martin: Slovenská národná knižnica, Archív literatúry a umenia, sign.: 210. Dostopno 14. 9.2010 na: http://www.snk.sk/?xxviii.

Milan HAMADA, 1994: Sizyfovský údel. Bratislava: Slovenský spisovatel'.

Milan HAMADA, 2008: Poézia katolíckej moderny. Bratislava: Kalligram, Ústav SL SAV.

Georg LANGENHORST, 2005: Theologie \& Literatur. Darmstadt: Wissenschaftliche Buchgesellschaft.

Ansgar NÜNNING, 2006: Lexikon teorie literatury a kultury. Brno: Host.

Július PAŠTEKA, 1995: Poznámky editora. Súborné dielo Janka Silana 1. Ur. Július Pašteka. Bratislava: Lúč. 229-237.

Július PAŠTEKA, 1998: Koniec a začiatok. Súborné dielo Janka Silana 8. Ur. Július Pašteka. Bratislava: Lúč. 5-22.

Július PAŠTEKA, 2002: Tvár a tvorba slovenskej katolíckej moderny. Bratislava: Lúč.

Rainer MARIA RILKE, 1971: Píseň o lásce a smrti korneta Kryštofa Rilka. Praha: Vyšehrad.

Janko SILAN, 1936: Kuvici. Praha: Knihtiskárna Vladislava Burdy.

Janko SILAN, 1998: Súborné dielo Janka Silana 8. Ur. Július Pašteka. Bratislava: Lúč.

Jozef VOJVODÍK, 2004: Od estetismu k eschatonu. Praha: Academia.

Ján ZAMBOR, 1998: Janko Silan. Portréty slovenských spisovatel’ov 1. Ur. J. Zambor. Bratislava: UK Bratislava. 40-52.

\section{THE IMAGE OF MODERNITY IN JANKO SILAN'S ČUKI}

This interpretation of Silan's debut poetry collection, Kuvici (The Screech Owls), respects its division into four parts. The outlines of the interpretation are determined by the categories of lyrical subject, figurativity and sensuality. Thus we can discover various typological levels of modernist expression inspired by both domestic and foreign literary models, including folklore, Slovak and Czech Modernism, French Decadence, and Catholic Modernism.

The book expresses the problem of several anthropological themes as a result of the author's modernist inspirations and his own life experience. Imagination in the book is based on sensual impressions. Silan used certain visual impulses productively yet originally, which work as a source of semantic tension (i.e. blind eyes). Particular sen- 
sual metaphors are frequently interconnected with synesthetic expressions. The autoreferential utterance of the lyrical subject moves between the figurative axes "tartaros" - "eros" - "sacros", corresponding to the decadent, erotic, and spiritual.

On this basis it is possible to characterize the literary style of Silan as subjective and symbolist, decadent and modernist. Silan used only some of the means of expression typical of modernism, according to his poetic intention. Some typical modernist features remained unused, such as the blasphemous decadence and the sense of guilt of the lyrical subject typical of Slovak Literary Modernism. Despite all these tendencies, however, Silan kept the criteria of both functional order and creativity. Although in the context of Slovak literary history Janko Silan is regarded as a spiritual poet par excellence, many of the poetic features of his debut poetry collection stand in opposition to this main characteristic. Silan can be considered a representative of the modernist school without any negative reference to the literary and folkloric tradition. 